\title{
USE OF FINANCIAL AND NON-FINANCIAL INDICATORS IN EVALUATION OF COMPANY'S PERFORMANCE
}

\author{
Inta Kotane ${ }^{1}$
}

\begin{abstract}
Dimensions for the measurement of the company's performance include financial and non-financial indicators. Many authors have carried out researches on financial and non-financial indicators, though the problems of their practical application exist, since there is no single united approach for measurement and assessment of both financial and non-financial indicators. This research is based on the former theoretical and practical researches by the author on the application of the financial and non-financial indicators to measure the company's performance.

The aim of this research was to develop a model for the small companies' performance evaluation, based on the opinions of the owners, managers, and top executives of the small companies in Latvia. The Internet survey was used as a research method, applying a simple random sampling. The results of the research indicated that there are 17 indicators, including 10 financial and 7 non-financial indicators, which could be used for the evaluation of the small companies’ performance and for modelling the company’s net turnover.
\end{abstract}

JEL Classification Numbers: G30, M21, C30, DOI: http://dx.doi.org/10.12955/cbup.v3.605

UDC Classification: 330.1

Keywords: financial indicators, non-financial indicators, company’s performance, multiple variable model

\section{Introduction}

To characterize the results of the company's operations, the term "performance" is used in foreign research and study literature. Lebas (1995) considers that the performance is never objective; it is only a way of defining where one wants to go.

"Performance" is an interesting concept (Berger \& Luckmann, 1966). "Performance" is not an objective reality out there somewhere waiting to be measured and evaluated. "Performance"' is a socially constructed reality. Laitinen (2002) defines the performance as an ability of an object to produce results in a dimension determined a priori, in relation to a target. Thus, it is necessary to have, first, an object whose performance is to be considered; second, a dimension in which one is interested; and, third, a set target for the result. Folan, Browne, \& Jagdev (2007) supposes that the performance is governed by the following three priorities: (1) it is always made as per the deemed relevance of an entity to a particular environment (thus, we commonly assess a company on its impact, for example, in a particular market...); (2) it is always made with a relevant objective in mind (thus, we commonly assess a company as per some set future vision on what the company wants to achieve...); (3) it is always reduced to relevant, recognizable characteristics (thus, we commonly assess a company on competitive parameters, such as cost, quality, time, etc., and more harder-to-measure competitive priorities, such as flexibility, or sustainability, because they are relevant and recognizable, etc.).

It could be concluded that the company's performance can be described as an ability of the company to represent itself to the outside, using the performance indicators that characterize activities and achievements of the company in relation to its goals, thus creating an overall opinion about the company.

Interest on the issues of the performance measurement and management has increased during the last twenty years (Taticchi, Tonelli, \& Cagnazzo, 2010; Yadav \& Sagar, 2013).

The analysis of the researches on the frameworks of the performance measurement (Neely, Gregory, \& Platts, 2005; Folan \& Browne, 2005; Folan et al., 2007; Taticchi et al., 2010; Watts \& McNairConnolly, 2012; Susilawati, Tan, Bell, \& Sarwar, 2013) indicates that the dimensions of the company's performance measurement include financial and non-financial indicators. Uyar (2010) believes that the

\footnotetext{
${ }^{1}$ Inta Kotane, Riga International School of Economics and Business Administration and Rezekne Higher Education Institution, Latvia, inta@ru.lv
} 
performance measurement tools could be classified as traditional including financial measures and new approaches including non-financial measures along with financial ones. The financial and nonfinancial indicators used in the researches on the evaluation of the company's performance reveal their diversity. In the evaluation of the companies' non-financial and/or financial performance, various number of the indicators have been used: 3 non-financial and 3 financial indicators (Zeng, Meng, Yin, Tam, \& Sun, 2010), 11 non-financial and 5 financial indicators (Fernandes, Raja, \& Whalley, 2006), 6 non-financial and 2 financial indicators (Krumwiede, Swain, Thornock, \& Eggett, 2013), 9 non-financial indicators (Coram, Mock, \& Monroe, 2011), 12 non-financial and 4 financial indicators (Cardinaels \& Van Veen-Dirks, 2010), 5 non-financial and 5 financial indicators (Prieto \& Revilla, 2006 ), 14 nonfinancial indicators (Hoque, 2005), 23 non-financial and 8 financial indicators (Phillips \& Louvieris, 2005), 10 non-financial and 2 financial indicators (Craig \& Moores, 2005), 12 financial indicators (Wen, Chen, \& Chen, 2008), etc. Lack of a united approach to the use of financial and nonfinancial indicators for evaluation of the company's financial and/or non-financial performance leads to the problem of their practical application. The author has carried out an assessment of the financial and non-financial indicators that are used in the evaluation of financial and non-financial performance of the companies, and as a result has established the sets of financial and non-financial indicators that are used in the practical research.

The performance measurements include not only assessment of the individual impact of the financial and non-financial indicators on the company's performance, but also determination of the joint impact of the financial and non-financial indicators. The small and medium-sized companies' performance evaluation model in a form of mathematical expression is developed (Sousa, Aspinwall, \& Rodrigues, 2006), based on the replies provided by 48 respondents regarding various aspects of the company's performance evaluation system using Likert scale, where " 1 " represents "Strongly agree" and " 5 " "Strongly disagree." Performance measurement model for the agriculture companies is developed (Harif, Hoe, \& Ahmad, 2013), based on the interviews with 27 respondents. Main and supplementing financial and non-financial indicators are defined without integrating them in one combined model in a form of mathematical relationship.

The researches on the companies' performance measurement using financial and non-financial indicators have not been carried out in Latvia; that defines the timely character of the research topic.

Within the framework of the current research, considering the limited scope of the research, the use of financial and non-financial indicators for evaluation of the company's performance was carried out on the base of the companies' survey on the significance of the financial and non-financial indicators in the evaluation of the companies' performance and impact of the financial and non-financial indicators on changes of the company's net turnover.

The aim of the research: to develop the small companies' performance evaluation model based on the opinions of the owners, managers, and top executives of the Latvian small companies.

In order to accomplish the aim of the research the following objectives were established:

- to evaluate an impact of the assessment of the significance of financial and non-financial indicators on the company's net turnover;

- to describe the developed small companies’ performance evaluation model and to provide its interpretation.

Research subject: financial and non-financial indicators.

The research methods used in the research: information analysis and synthesis, logically constructive method, methods of data classification, comparative method. 


\section{Materials and methods}

The current practical research is based on the theoretical studies by the author on the use of the financial and non-financial indicators in the evaluation of the business performance (Kotane \& Kuzmina-Merlino, 2011; 2012a). To approbate the theoretical statements, the author has used the Internet survey applying the random sampling method and has surveyed 208 Latvian companies in August and September 2012. The Latvian business persons and top-level employees of the Latvian companies, who are the users of the internal information making various operational and financial decisions, were surveyed: owners and top managers of the companies, heads of the structural units, heads, and employees of financial departments. The aim of the survey was to establish the system of indicators for the evaluation of the business performance, which could be used by the managers to evaluate in an integrated way and to control efficiently the financial position of the company in the circumstances of the growing competition. The system of indicators would include both the set of specific financial indicators and non-financial indicators that would demonstrate the internal potential and future development possibilities of the company.

The results of the former researches by the author (Kotane, 2012b; 2013) have indicated the differences in the assessment of the significance of financial and non-financial indicators by small enterprises (10-49 employees) and micro enterprises (1-9 employees); therefore, the performance evaluation model was developed for small enterprises, based on the replies provided by 60 respondents representing small companies.

Table 1 shows that, among the respondents of the survey, $47.1 \%$ are business owners (35.0\% - among the respondents representing the small companies).

\begin{tabular}{|c|c|c|c|c|c|}
\hline $\begin{array}{l}\text { Position of the respondent in the } \\
\text { company }\end{array}$ & all & small & Main business sector & all & small \\
\hline Company owners & 47.1 & 35.0 & $\begin{array}{l}\text { (A) Agriculture, forestry and } \\
\text { fishing }\end{array}$ & 10.1 & 15.0 \\
\hline Company managers & 24.5 & 30.0 & (B) Mining and quarrying & 5.8 & 5.0 \\
\hline Company unit manager & 4.3 & 10.0 & (C) Manufacturing & 15.9 & 30.0 \\
\hline $\begin{array}{l}\text { Company financial department } \\
\text { staff }\end{array}$ & 12.5 & 10.0 & (F) Construction & 8.7 & 10.0 \\
\hline $\begin{array}{l}\text { Company financial department } \\
\text { managers }\end{array}$ & 11.5 & 15.0 & $\begin{array}{l}\text { (G) Wholesale and retail trade; } \\
\text { repair of motor vehicles and } \\
\text { motorcycles }\end{array}$ & 24.5 & 20.0 \\
\hline Average number of employees & all & small & (S) Other services activities & 14.9 & - \\
\hline 1 - 9 employees & 55.3 & - & \multirow{2}{*}{$\begin{array}{l}\text { (M) Professional, research and } \\
\text { technical activities }\end{array}$} & \multirow{2}{*}{5.8} & \multirow{2}{*}{5.0} \\
\hline 10 - 49 employees & 28.8 & 100.0 & & & \\
\hline 50 - 249 employees & 14.4 & - & Others & 14.4 & 15.0 \\
\hline More than 250 employees & 1.4 & - & Year of foundation & all & small \\
\hline $\begin{array}{l}\text { Turnover in the last accounting } \\
\text { year }\end{array}$ & all & small & Before 1991 & 10.1 & 10.0 \\
\hline Less than $10,000 \mathrm{LVL}$ & 13.9 & - & $1991-1993$ & 21.6 & 25.0 \\
\hline
\end{tabular}




\begin{tabular}{|l|l|l|l|l|l|}
\hline $10,001-70,000$ LVL & 30.3 & 10.0 & $1994-2000$ & 23.1 & 30.0 \\
\hline 70,001 - 200,000 LVL & 18.3 & 15.0 & $2001-2007$ & 18.8 & 30.0 \\
\hline 200,001 - 500,000 LVL & 8.7 & 10.0 & $2007-2010$ & 16.8 & 5.0 \\
More than 500,000 LVL & 28.8 & 65.0 & After 2010 & 9.6 & - \\
\hline Source: Author & & \\
\hline
\end{tabular}

To define the category of the enterprise (micro, small, medium-sized or large), the criteria of average number of employees in the company were used. In accordance with the average number of employees, the largest share of the surveyed companies were those with the average number of employees from 1 to 9 (55.3\%). In accordance with the profile of the main business sector, the most of all surveyed companies and the most of the small companies, in particular, represented wholesale and retail trade, repairs of cars and motorcycles, and manufacturing. By the year of establishment, most of the companies in general and most of small companies, in particular, were those established between 1994 and 2000. By turnover in the last accounting year, the largest number of companies were those with net turnover from 10001 to 70000 LVL (until 01.01.2014. 1 EUR = 0.702804 LVL) (30.3\%).

In general, the respondents of the surveyed companies have various statuses, enterprises of various basic sectors of industry and foundation years, different number of employees and volume of net turnover are represented.

The five point Likert scale with a range from 1 ("not important”) to 5 ("highly important”) was used in the questionnaire to evaluate the importance of the financial and non-financial indicators for the evaluation of the business performance.

The companies' net turnover in the last accounting year was used as a final value and assessments of the significance of financial and non-financial indicators were used as factorial values in development of the small companies' performance measurement model, based on the multiple variable model. The model is created using the assessment, or, the significance of a financial or non-financial indicator and the company's net turnover in the accounting year. The categorised values were assigned to the net turnover; the data was analysed by the groups of the net turnover.

The author has carried out the linear and multiple regression analysis between the company's net turnover in the accounting year and financial and/or non-financial indicators. The regression coefficients obtained were used to create an equation. In the case of the linear regression, the inverse regression equation was formulated, where the value to be calculated is a value of financial and/or non-financial indicators. In the case of multiple regression, the multiple regression equation was formulated, which could be used to measure performance of small companies. The result was considered to be statistically significant if $\mathrm{p}<0.05$ or $\mathrm{p}<5.00 \times 10^{-2}$ (Liepa, 1974). If $\mathrm{p}<0.05$ or $5.00 \times 10^{-2}$, the statistically valid regression model is obtained. Evaluation $(\#)$ of the prognoses in the Tables 1-3 are provided in the case the regression model is statistically valid: $\uparrow$ - increase of the significance of financial/ non-financial indicators increases the company's net turnover; $\downarrow$ - decrease of the significance of financial/ non-financial indicators increases the company's net turnover. Designations in the regression equations are the following: $y$ - the company's net turnover in the accounting year, $\mathrm{x}$ - a particular financial/ non-financial indicator.

Designations of financial indicators used further in the text: net turnover (F1), cash-flow report (F2), current ratio (F3), asset turnover, times (F4), accounts receivable turnover (days/ times) (F5), inventory turnover (days/ times) (F6), payables turnover (days/ times) (F7), total debt ratio in the balance (F8), debt-to-equity ratio (F9), gross profitability (F10), return on assets (ROA) (F11), return 
on equity (ROE) (F12), return on sales (ROS) (F13), return on investments (ROI) (F14), EBITDA profitability (F15), DSCR (debt service coverage ratio) (F16).

Designations of non-financial indicators used further in the text: level of consumers satisfaction (NF1), increase of number of consumers (NF2), consumers loyalty (NF3), quality of the products / services (NF4), motivated employees (NF5), loyal employees (NF6), the level of employees satisfaction (NF7), development of new products/ services (NF8), training of employees (NF9), company reputation (NF10), market share (NF11).

Designations of factor groups used further in the text: solvency and profitability (F-SP), efficiency of assets use and financial stability (F-ES), evaluation of investment possibilities (F-I), role and influence of consumers (NF-C), role and influence of employees (NF-E).

The results of the survey were processed and analysed using SPSS and Excel software.

\section{Impact of individual indicators of financial and non-financial groups on the company's net turnover}

The author has performed the evaluation of the particular impact of each financial and non-financial indicator on the company's net turnover in the accounting year (Table 2).

Obtained results indicate that both financial ( $F 8, F 11, F 12, F 13, F 14$, and F15) and non-financial (NF5, NG8, and NF9)indicators have impact on the company's net turnover in the accounting year. To increase the company's net turnover, it is necessary to increase the significance of the particular indicator (F11, F12, F13, F14, NF5, and NF9) in the company. In the case of indicators F8 and NF8, it is necessary to reduce their significance in order to increase the company's net turnover in the accounting year.

On the basis of the results of the regression analysis, it could be concluded that six financial indicators F8, F11, F12, F13, F14, F15 and three non-financial indicators NF5, NF8, NF9 could be used separately to analyse the company's net turnover in the accounting year and its future planning.

Table 2: The results of analysis of impact of the individual indicators of statistically related factor groups of the small companies on the company's net turnover in the accounting year

\begin{tabular}{|c|c|c|c|c|c|c|c|c|}
\hline \multicolumn{2}{|c|}{$\begin{array}{r}\begin{array}{r}\text { Regression } \\
\text { indicators }\end{array} \\
\text { Indicator } \\
\text { and factor group }\end{array}$} & $\mathbf{R}^{2}$ & $\mathbf{R}^{2} \mathbf{P}^{*}$ & Constant & B & $\boldsymbol{\beta}$ & $\begin{array}{l}\text { Inversed } \\
\text { regression } \\
\text { equation }\end{array}$ & $\begin{array}{c}\text { Description } \\
\text { of } \\
\text { prognoses }\end{array}$ \\
\hline \multicolumn{9}{|c|}{ Financial indicators } \\
\hline F1 & F-ES & 0.00 & 0.66 & 4.06 & 0.07 & 0.06 & - & - \\
\hline F2 & F-SP & 0.00 & 0.83 & 4.16 & 0.04 & 0.03 & - & - \\
\hline F3 & F-SP & 0,03 & 0.20 & 3.48 & 0.24 & 0.17 & - & - \\
\hline F4 & F-SP & 0.00 & 0.93 & 4.25 & 0.02 & 0.01 & - & - \\
\hline F5 & F-ES & 0.00 & 0.71 & 4.12 & 0.05 & 0.05 & - & - \\
\hline F6 & F-ES & 0.02 & 0.27 & 4.77 & -0.14 & -0.14 & - & - \\
\hline F7 & F-ES & 0.01 & 0.36 & 3.88 & 0.13 & 0.12 & - & - \\
\hline F8 & F-ES & 0.07 & $3.67 \times 10^{-2}$ & 5.42 & -0.34 & -0.27 & $\mathrm{x}=(\mathrm{y}-5.42) /-0.34$ & $\downarrow$ \\
\hline F9 & F-SP & 0.01 & 0.53 & 4.03 & 0.08 & 0.08 & - & - \\
\hline F10 & F-SP & 0.07 & 0.05 & 2.57 & 0.47 & 0.26 & - & - \\
\hline F11 & F-SP & 0.23 & $9.76 \times 10^{-5}$ & 2.63 & 0.50 & 0.48 & $\mathrm{x}=(\mathrm{y}-2.63) / 0.50$ & $\uparrow$ \\
\hline
\end{tabular}


CBU I NTERNATIONAL CONFERENCE ON I NNOVATION, TECHNOLOGY TRANSFER AND EDUCATION

\begin{tabular}{|c|c|c|c|c|c|c|c|c|}
\hline F12 & F-SP & 0.45 & $3.78 \times 10^{-9}$ & 1.68 & 0.83 & 0.67 & $\mathrm{x}=(\mathrm{y}-1.68) / 0.83$ & $\uparrow$ \\
\hline F13 & F-SP & 0.07 & $4.62 \times 10^{-2}$ & 3.34 & 0.28 & 0.26 & $\mathrm{x}=(\mathrm{y}-3.34) / 0.28$ & $\uparrow$ \\
\hline F14 & F-I & 0.07 & $4.13 \times 10^{-2}$ & 3.47 & 0.27 & 0.26 & $\mathrm{x}=(\mathrm{y}-3.47) / 0.27$ & $\uparrow$ \\
\hline F15 & F-I & 0.15 & $2.36 \times 10^{-3}$ & 3.14 & 0.38 & 0.39 & $\mathrm{x}=(\mathrm{y}-3.14) / 0.38$ & $\uparrow$ \\
\hline F16 & F-I & 0.04 & 0.11 & 3.54 & 0.26 & 0.21 & - & - \\
\hline \multicolumn{7}{|c|}{ Non-financial indicators } & - \\
\hline NF1 & NF-C & 0.04 & 0.15 & 5.00 & -0.19 & -0.19 & - & - \\
\hline NF2 & NF-C & 0.00 & 0.83 & 4.16 & 0.04 & 0.03 & - & - \\
\hline NF3 & NF-C & 0.00 & 0.64 & 4.03 & 0.07 & 0.06 & - & - \\
\hline NF4 & NF-C & 0.00 & 1.00 & 4.30 & 0.00 & 0.00 & - & - \\
\hline NF5 & NF-E & 0.12 & $6.19 \times 10^{-3}$ & 2.00 & 0.59 & 0.35 & $\mathrm{x}=(\mathrm{y}-2.00) / 0.59$ & $\uparrow$ \\
\hline NF6 & NF-E & 0.01 & 0.54 & 4.70 & -0.10 & -0.08 & - & - \\
\hline NF7 & NF-E & 0.06 & 0.05 & 2.92 & 0.37 & 0.25 & - & $\downarrow$ \\
\hline NF8 & NF-E & 0.12 & $7.29 \times 10^{-3}$ & 6.48 & -0.58 & -0.34 & $\mathrm{x}=(\mathrm{y}-6.48) /-0.58$ & $\downarrow$ \\
\hline NF9 & NF-E & 0.16 & $1.43 \times 10^{-3}$ & 2.50 & 0.55 & 0.40 & $\mathrm{x}=(\mathrm{y}-2.50) / 0.55$ & $\uparrow$ \\
\hline NF10 & NF-C & 0.05 & 0.08 & 5.44 & -0.29 & -0.23 & - & - \\
\hline NF11 & NF-C & 0.00 & 0.72 & 4.50 & -0.05 & -0.05 & - & - \\
\hline S6
\end{tabular}

Source: Author

\section{Impact of the evaluation of significance of the financial and non-financial indicators on the company's net turnover}

Multiple regression is used to link all the statistically significant indicators in one equation (Table 3) hence it could be observed that all of them jointly explain $85.0 \%$ of formation of the net turnover. If separate impact of each indicator is considered, it is possible to see that, in the case of financial indicators F8 and F15, their impact on the increase of the company's net turnover changes in comparison with individual impact (Table 2).

\begin{tabular}{|c|c|c|c|c|c|c|}
\hline \multirow{2}{*}{ Indicator } & \multicolumn{5}{|c|}{ Regression indicators } & \multirow{2}{*}{$\begin{array}{c}\text { Description of } \\
\text { prognoses }^{\#}\end{array}$} \\
\hline & $\mathbf{R}^{2}$ & $\mathbf{R}^{2} \mathbf{P}^{*}$ & $\mathbf{B}$ & $\boldsymbol{\beta}$ & $\mathbf{P}$ & \\
\hline Constant & \multirow{10}{*}{0.85} & \multirow{10}{*}{$\begin{array}{c}8.53 \times 10^{-} \\
18\end{array}$} & 2.51 & & $9.58 \times 10^{-4}$ & \\
\hline F8 & & & 0.10 & 0.08 & 0.52 & $\uparrow$ \\
\hline F11 & & & 0.80 & 0.76 & $4.27 \times 10^{-6}$ & $\uparrow \uparrow$ \\
\hline F12 & & & 0.55 & 0.45 & $7.07 \times 10^{-6}$ & $\uparrow$ \\
\hline F13 & & & -0.76 & -0.70 & $9.82 \times 10^{-7}$ & $\downarrow$ \\
\hline F14 & & & 0.14 & 0.14 & 0.26 & $\bar{\uparrow}$ \\
\hline F15 & & & -0.09 & -0.09 & 0.37 & $\downarrow$ \\
\hline NF5 & & & 0.45 & 0.26 & $4.82 \times 10^{-2}$ & $\uparrow$ \\
\hline NF8 & & & -0.91 & -0.54 & $3.00 \times 10^{-6}$ & $\downarrow$ \\
\hline NF9 & & & 0.37 & 0.27 & $4.28 \times 10^{-3}$ & $\bar{\uparrow}$ \\
\hline Source: Author & & & & & & \\
\hline
\end{tabular}


If an individual or particular impact of the financial indicator $F 8$ on the company's net turnover is assessed without changing impact of other indicators, the significance of $F 8$ should be reduced to increase the company's net turnover in the accounting year. In the multiple regression equation, the impact of the financial indicator F8 on the company's net turnover is considerably lower (3.4 times); moreover, the impact is direct: increasing of $F 8$ significance will lead to increase of the company's net turnover.

If individual or particular impact of the financial indicator F15 on the company's net turnover is assessed without changing impact of other indicators, the significance of the financial indicator F15 should be increased to increase the company's net turnover in the accounting year. In the multiple regression equation, the significance of the financial indicators F15 should be reduced to enhance increase of the company's net turnover.

Taking into account that, in accordance with the results of the concordance analysis, only 2 (F13 and NF5) out of 9 financial and non-financial indicators depicted in the Table 3 have received the highest evaluation by the respondents, the author has added indicators of the financial and non-financial groups, ranged by the respondents to the top five places in the financial or non-financial range, in the Table 4. In the result of calculations (Table 4), the author concludes that these financial and nonfinancial indicators in general explain $100 \%$ of the company's net turnover in the accounting year.

Table 4: Multiple regression analysis between the evaluation of the significance of financial and non-financial indicators and the company's net turnover in the accounting year.

\begin{tabular}{|c|c|c|c|c|c|c|}
\hline \multirow{2}{*}{$\begin{array}{l}\text { Indicator (range by } \\
\text { concordance) }\end{array}$} & \multicolumn{5}{|c|}{ Regression indicators } & \multirow{2}{*}{$\begin{array}{c}\text { Description of } \\
\text { prognoses }^{\#}\end{array}$} \\
\hline & $\mathbf{R}^{2}$ & $\mathbf{R}^{2} \mathbf{P}^{*}$ & B & $\boldsymbol{\beta}$ & $\mathbf{P}$ & \\
\hline Constant & \multirow{18}{*}{1,00} & \multirow{18}{*}{$\underset{43}{1,30 \times 10^{-}}$} & -2.23 & & $7.82 \times 10^{-9}$ & \\
\hline F1 (2-4) & & & 0.43 & 0.37 & $1.36 \times 10^{-20}$ & $\uparrow$ \\
\hline F2 (1) & & & -0.47 & -0.37 & $1.36 \times 10^{-19}$ & $\downarrow$ \\
\hline F5 (2-4) & & & -0.07 & -0.07 & $3.21 \times 10^{-2}$ & $\downarrow$ \\
\hline F8 & & & 0.91 & 0.73 & $1.67 \times 10^{-22}$ & $\uparrow$ \\
\hline F10 (2-4) & & & $-0,90$ & -0.49 & $6.78 \times 10^{-18}$ & $\downarrow$ \\
\hline F11 & & & 1.51 & 1.44 & $2.20 \times 10^{-21}$ & $\uparrow$ \\
\hline F12 & & & -0.22 & -0.18 & $1.08 \times 10^{-5}$ & $\downarrow$ \\
\hline F13 (5) & & & $\begin{array}{l}-0.13 \\
\end{array}$ & -0.12 & $2.35 \times 10^{-3}$ & $\downarrow$ \\
\hline F14 & & & 0.05 & 0.05 & 0.11 & $\uparrow$ \\
\hline F15 & & & 0.01 & 0.01 & 0.69 & $\uparrow$ \\
\hline NF3 (5) & & & -0.17 & -0.15 & $9.93 \times 10^{-7}$ & $\downarrow$ \\
\hline NF4 (1-2) & & & -0.24 & -0.19 & $5.19 \times 10^{-5}$ & $\downarrow$ \\
\hline NF5 (3-4) & & & 3.36 & 1.99 & $3.93 \times 10^{-27}$ & $\uparrow$ \\
\hline NF6 (3-4) & & & -2.86 & -2.25 & $6.21 \times 10^{-26}$ & $\downarrow$ \\
\hline NF8 & & & 0.10 & 0.06 & 0.09 & $\bar{\uparrow}$ \\
\hline NF9 & & & 0.05 & 0.04 & 0.34 & $\uparrow$ \\
\hline NF10 (1-2) & & & 0.59 & 0.47 & $4.88 \times 10^{-21}$ & $\uparrow$ \\
\hline
\end{tabular}




\section{Interpretation of the small companies' business efficiency evaluation model}

If the final value is the company's net turnover in the accounting year, the small companies' performance evaluation could be carried out using ten financial indicators and seven non-financial indicators (See Figure 1). The direct impact of the company's indicators supposes to increase the significance of these indicators, and the reverse impact assumes to reduce the significance of these indicators in order to increase the company's net turnover.

On the basis of the description of the coefficient B and prognoses provided in Table 4 and Figure 1, it could be observed that the direct impact exists, therefore, the significance of the following indicators financial indicators $F 1, F 8, F 11, F 14$, and $F 15$ and non-financial indicators $N F 5, N F 8, N F 9$, and NF10 - should be increased in order to increase the company's net turnover. The reverse impact of the indicators on the company's net turnover exists and, therefore, the significance of the following indicators - financial indicators F2, F5, F10, F12, and F13 and non-financial indicators NF3, NF4, and NF6 - should be reduced to increase the company's net turnover.

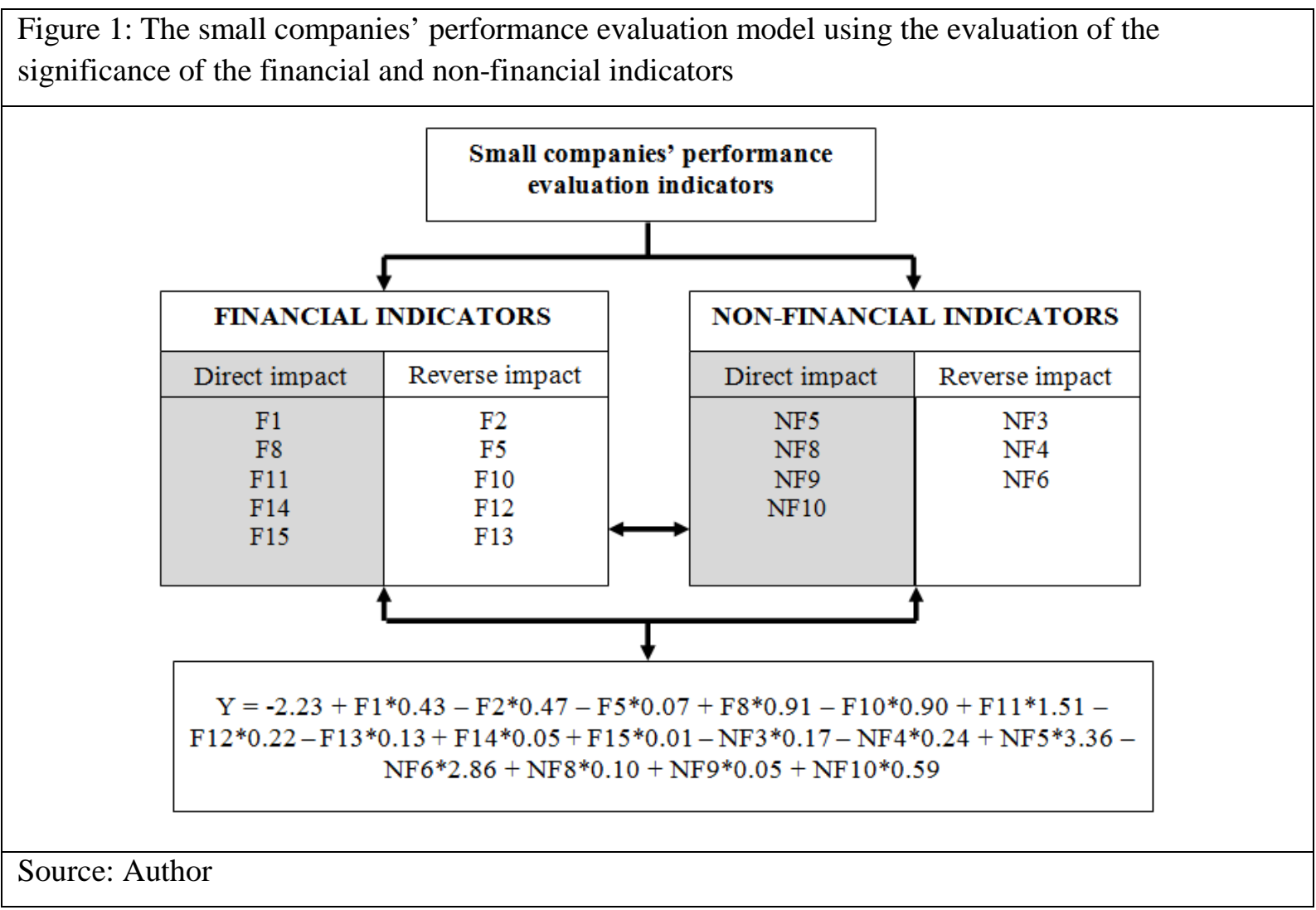

The author, using Table 4, has created a regression equation and tested it practically obtaining Y lower and upper theoretically possible value that could be described as the lower and the upper limits (See: Figure 2).

$\mathrm{Y}=27.6$ indicates that all the indicators of the direct impact are evaluated as extremely significant (5) and all indicators of the reverse impact are evaluated as insignificant (1). In the particular case, the evaluation of the significance of indicators creates preconditions for the increase of the company's net

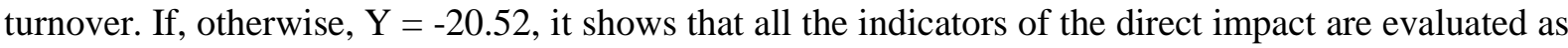
insignificant (1) and all the indicators of the reverse impact-as extremely significant (5). The particular situation demonstrates that evaluation of the indicators' significance does not enhance increase of the company's net turnover; therefore, it would be necessary to review the evaluation of the indicators' significance. If $\mathrm{Y}=3.62$, all indicators are evaluated as having average significance, 
there is no special attention paid to the particular indicator, hence, the company's net turnover will not change.

\begin{tabular}{|l|c|c|}
\hline Figure 2: Theoretical limits of the small companies' performance evaluation model \\
$\qquad \begin{array}{c}\text { Direct impact } \\
\text { indicators }=1 \\
\text { Reverse impact } \\
\text { indicators }=5\end{array}$ \\
\cline { 2 - 3 }
\end{tabular}

\section{Conclusion}

The author proposes to use seventeen indicators for the small companies' performance evaluation and the company's net turnover modelling. These include ten financial indicators: (F1), cash-flow report (F2), accounts receivable turnover (days/times) (F5), total debt ratio in the balance (F8), gross profitability (F10), return on assets (ROA) (F11), return on equity (ROE) (F12), return on sales (ROS) (F13), return on investments (ROI) (F14), EBITDA profitability (F15), and seven non-financial indicators: consumers loyalty (NF3), quality of the products/services (NF4), motivated employees (NF5), loyal employees (NF6), development of new products/services (NF8), training of employees (NF9), and company's reputation (NF10).

\section{References}

Berger, P. L., \& Luckmann, T. L.(1966). The Social Construction of Reality. Garden City, NY: Doubleday.

Cardinaels, E., \& Van Veen-Dirks, P. M. G. (2010). Financial versus non-financial information: The impact of information organization and presentation in a Balanced Scorecard. Accounting, Organizations and Society, 35, 565-578. doi: 10.1016/j.aos.2010.05.003

Coram, P. J., Mock, T. J., \& Monroe, G. S. (2011). Financial analysts' evaluation of enhanced disclosure of non-financial performance indicators. The British Accounting Review, 43(2), 87-101. doi: 10.1016/j.bar.2011.02.001

Craig, J., \& Moores, K. (2005). Balanced Scorecards to drive the strategic planning of family firms. Family business review, XVIII(2), 105-122. doi: 10.1111/j.1741-6248.2005.00035.X

Fernandes, K. J., Raja, V., \& Whalley, A. (2006). Lessons from implementing the balanced scorecard in a small and medium size manufacturing organization. Technovation, 26, 623-634. doi:10.1016/j.technovation.2005.03.006

Folan, P., \& Browne, J. (2005) A review of performance measurement: Towards performance management. Computers in Industry, 56, 663-680.

Folan, P., Browne, J., \& Jagdev, H. (2007). Performance: Its meaning and content for today's business research. Computers in Industry, 58, 605-620. doi: 10.1016/j.compind.2007.05.002

Harif, M. A. A. M., Hoe, C. E., \& Ahmad, M. I. (2013). The Financial and Non-Financial Performance Indicators of Paddy Farmers' Organizations in Kedah. World Review of Business Research, 3(1), 80-102.

Hoque, Z. (2005). Linking environmental uncertainty to non-financial performance measures and performance: a research note. The British Accounting Review, 37, 471-481. doi: 10.1016/j.bar.2005.08.003

Kotane, I., \& Kuzmina-Merlino, I. (2012a). Assessment of financial indicators for evaluation of business performance. European integration studies, 6, 216-224.

Kotane, I. (2012b). The role of the analysis of financial and non-financial indicators in assessment of performance of the companies. Management theory and studies for rural business and infrastructure development, 34, 93.-104. 
Kotane, I. (2013). The evaluation of financial and non-financial indicators in evaluating the performance of company. Latgale national economy research, 5, 129.-147.

Kotane, I., \& Kuzmina-Merlino, I. (2011). Non-financial indicators for evaluation of business activity. European integration studies, 5, 213.219

Krumwiede, K. R., Swain, M. R., Thornock, T. A., \& Eggett, D. L. (2013). The effects of task outcome feedback and broad domain evaluation experience on the use of unique scorecard measures. Advances in Accounting, 29(2), 205-217. doi: 10.1016/j.adiac.2013.05.002

Laitinen, E. K. (2002). A dynamic performance measurement system: evidence from small Finish technology companies. Scandinavian Journal of Management, 18(1), 65-99. doi: 10.1016/S0956-5221(00)00021-X

Lebas, M. J. (1995). Performance measurement and performance management. International Journal of Production Economics, 41(1-3), 23.-35. doi: 10.1016/0925-5273(95)00081-X

Liepa, I. (1974). Biometrija. Rīga, Zvaigzne.

Neely, A., Gregory, M., \& Platts, K. (2005). Performance measurement system design. A literature review and research agenda. International Journal of Operations \& Production Management, 25(12), 1228-1263. doi: 10.1108/01443570510633639

Phillips, P., \& Louvieris, P. (2005). Performance measurement systems in tourism, hospitality and leisure small mediumsized enterprises: a balanced scorecard perspective. Journal of Travel Research, 44, 201-211. doi:10.1177/0047287505278992

Prieto, I. M., \& Revilla, E. (2006). Learning capability and business performance: a non-financial and financial assessment. Learning Organization, 13(2), 166 - 185. doi: 10.1108/09696470610645494

Sousa, S. D., Aspinwall, E. M., \& Rodrigues, A. G. (2006). Performance measures in English small and medium enterprises: survey results. Benchmarking: An International Journal, 13(1/2), 120-134.

Susilawati, A.,Tan, J., Bell, D., \& Sarwar, M. (2013). Develop a framework of performance measurement and improvement system for lean manufacturing activity. 3rd International Conference on Trends in Mechanical and Industrial Engineering, January 8-9, Kuala Lumpur (Malaysia). Retrieved from http://psrcentre.org/images/extraimages/113700.pdf

Taticchi, P., Tonelli, F., \& Cagnazzo, L. (2010). Performance measurement and a management: a literature review and a research agenda. Measuring Business Excellence, 14(1), 4-18. doi:10.1108/13683041011027418

Uyar, A. (2010). Development of non-financial measures as contemporary performance measurement tools. World of Accounting Science, 12(1), 209-238.

Watts, T., \& McNair-Connolly, C. J. (2012). New Performance Measurement and Management Control Systems. Journal of Applied Acounting Research, 13(3), 226-241. doi: 10.1108/09675421211281308

Wen, W., Chen, Y. H., \& Chen, I. C. (2008). A knowledge-based decision support system for measuring enterprise performance. Knowledge-Based Systems, 21(2), 148.-163. doi: 10.1016/j.knosys.2007.05.009

Yadav, N., \& Sagar, M. (2013). Performance measurement and management frameworks: Research trends of the last two decades. Business Process Management Journal, 19(6), 947 - 971. doi: 10.1108/BPMJ-01-2013-0003

Zeng, S. X., Meng, X. H., Yin, H. T., Tam, C. M., \& Sun, L. (2010). Impact of cleaner production on business performance. Journal of Cleaner Production, 18(10-11), 975-983. doi: 10.1016/j.jclepro.2010.02.019 